\title{
NILAI INDEKS GLIKEMIK BEBERAPA JENIS PENGOLAHAN JAGUNG MANIS (Zea mays saccharata Sturt)
}

\author{
(Glycemic Index Values of Sweet Corn (Zea mays saccharata Sturt) with Some Kind of Processing)
}

\author{
Sri Nur Amalia ${ }^{1}$, Rimbawan $^{1}$, dan Mira Dewi ${ }^{1 *}$
}

1 Departemen Gizi Masyarakat, Fakultas Ekologi Manusia, Institut Pertanian Bogor, Bogor 16680.

* Alamat korespondensi: Departemen Gizi Masyarakat, Fakultas Ekologi Manusia, Institut Pertanian Bogor, Bogor 16680. Telp: 0251-8621258; Fax: 0251-8622276, Email: miradewi@yahoo.com

\begin{abstract}
The implementation of glycemic index can be used as basis for selecting carbohydrate food source to enhance and or to maintain health. The objective the following study was to analyze the glycemic indices of sweet corn with three different cooking methods. Glycemic index values of boiled, sauted and grilled sweet corn were 41.22, 31.08 and 55.31 respectively. Based on those results, grilled sweet corn was classified as food with medium glycemic index, whereas both of boiled and sauted sweet corn were classified as food with low glycemic index.
\end{abstract}

Key words: glycemic index, sweet corn

\section{PENDAHULUAN}

Pada tahun 1981, Jenkins memperkenalkan konsep indeks glikemik (IG) yang mengelompokkan karbohidrat berdasarkan efeknya terhadap glukosa darah setelah pangan dikonsumsi. Penerapan konsep IG dapat digunakan sebagai acuan dalam menentukan jumlah dan jenis pangan sumber karbohidrat yang tepat untuk meningkatkan dan menjaga kesehatan. Indeks glikemik pangan adalah nilai yang menunjukkan bagaimana efek makanan (khususnya karbohidrat) terhadap glukosa darah setelah makan (Jenkins et al., 1981 dalam Widowati, 2006). Adapun faktor-faktor yang dapat mempengaruhi IG pada pangan antara lain: cara pengolahan (tingkat gelatinisasi pati dan ukuran partikel), perbandingan amilosa dengan amilopektin, tingkat keasaman dan daya osmotik, kadar serat, kadar lemak dan protein, serta kadar zat anti gizi pangan (Rimbawan dan Siagian, 2004).

Pemilihan pangan dengan nilai IG rendah bermanfaat untuk menjaga kestabilan gula darah. Hal ini sangat bermanfaat untuk mencegah penyakit degeneratif, misalnya diabetes mellitus (DM). Selain DM, obesitas juga merupakan contoh penyakit yang terkait erat dengan IG. Makanan dengan IG rendah dapat dijadikan pilihan untuk menurunkan berat badan ataupun menjaga agar berat badan tetap ideal (Radulian et al., 2009). Selain itu pangan dengan nilai IG rendah juga direkomendasikan untuk mempertahankan kesehatan.
Proses pengolahan dapat meningkatkan kadar IG pangan karena melalui proses pengolahan struktur pangan menjadi lebih mudah untuk dicerna dan diserap sehingga dapat mengakibatkan kadar gula darah meningkat cepat. Sebagai contoh proses pemasakan atau pemanasan yang akan menyebabkan pati tergelatinisasi. Dengan terjadinya proses gelatinisasi pati tersebut berarti molekul pati akan lebih mudah untuk dicerna karena enzim pencernaan pada usus mendapatkan tempat bekerja yang lebih luas (Rimbawan dan Siagian, 2004).

Jagung merupakan salah satu bahan makanan sumber karbohidrat yang cukup dikenal di masyarakat. Hal ini ditunjukkan dengan keberadaannya pada posisi ketiga sebagai makanan pokok dunia setelah gandum dan padi. Di Indonesia, jagung menempati urutan kedua sebagai pangan penting setelah nasi.

Selain dijadikan makanan pokok oleh beberapa suku di Indonesia, jagung juga sering dijadikan makanan cemilan oleh masyarakat dengan berbagai macam pengolahannya. Berdasarkan data BPS produksi dan konsumsi jagung pada tahun 2009 berkisar 17.66 ton pipilan kering (Anonim 2010).

Jagung manis merupakan salah satu jenis jagung yang popular dan disukai oleh masyarakat. Di Indonesia, jagung manis mulamula dikenal dalam bentuk kalengan. Jagung manis semakin popular dan banyak disukai konsumen karena memiliki rasa yang lebih manis dibandingkan jagung bijian (Palungkun dan Budiarti, 1992). Meskipun demikian, data me- 
ngenai IG jagung manis masih belum tersedia sehingga perlu dilakukan penelitian mengenai IG jagung manis dalam berbagai macam pengolahan yang sering dilakukan, yaitu rebus, tumis dan bakar.

Tujuan umum penelitian ini adalah untuk menganalisis nilai IG jagung manis yang diolah dengan cara rebus, tumis, dan bakar. Tujuan khusus penelitian ini adalah: 1). Mempelajari komposisi zat gizi (kadar air, abu, lemak, protein, serat, dan karbohidrat) yang terkandung di dalam jagung manis rebus, tumis, dan bakar, 2). Menganalisis nilai indeks glikemik jagung manis rebus, tumis, dan bakar, 3). Menganalisis pengaruh pengolahan terhadap nilai indeks glikemik jagung manis rebus, tumis, dan bakar.

\section{METODE PENELITIAN}

\section{Tempat dan Waktu Penelitian}

Penelitian ini dilaksanakan pada bulan Mei sampai bulan Juli 2010 di Laboratorium Percobaan Makanan, Laboratorium Kimia dan Analisis Gizi serta Ruang Teaching Cafetaria Departemen Gizi Masyarakat, Fakultas Ekologi Manusia, Institut Pertanian Bogor.

\section{Jumlah dan Penentuan Subjek}

Tahapan pengukuran indeks glikemik dimulai dengan perekrutan subjek. Kriteria inklusi antara lain adalah pria atau wanita, sehat, berumur 18 - 30 tahun, indeks massa tubuh normal (Sherwood, 2001). Kriteria eksklusi meliputi; memiliki riwayat DM, masalah pencernaan, merokok dan menggunakan obatobatan terlarang. Penelitian telah mendapatkan izin oleh Komisi Etik Penelitian Kesehatan Badan Penelitian dan Pengembangan Kesehatan (KEPK-BPPK) RI dengan nomor: LB. 03.04/ KE/4914/2010. Calon subjek yang bersedia berpartisipasi diminta untuk mengisi surat pernyataan kesediaan (informed consent). Jumlah subjek untuk tiap jenis pangan uji adalah 6 orang yang terdiri atas 3 pria dan 3 wanita.

\section{Prosedur Penentuan IG}

Tiga produk olahan jagung yang digunakan pada penelitian adalah jagung manis rebus, tumis, dan bakar. Ketiga cara pengolahan tersebut dipilih untuk mewakili metode pengolahan makanan yang biasa dilakukan di masyarakat. Langkah-langkah pengolahan dikerjakan menurut Widyati (2001).
Setelah dihasilkan tiga produk olahan jagung manis, tahap selanjutnya adalah analisis proksimat produk meliputi analisis kandungan air (metode oven biasa), protein (metode kjedahl), lemak (metode ekstraksi soxhlet), abu (metode pengabuan), dan karbohidrat by difference, total serat makanan (metode enzimatis), dan derajat gelatinisasi dengan metode IRRI 1978 (Fardiaz et al., 1984).

Penentuan IG pangan adalah sebagai berikut (Miller et al. 1997):

a. Setelah subjek berpuasa selama lebih kurang 10 jam, dilakukan pengukuran kadar glukosa darah perifer dari finger prick capillary blood dengan glukometer. Setelah itu, pada subjek diberikan $50 \mathrm{~g}$ glukosa murni yang dilarutkan dalam 150 cc air sebagai pangan acuan.

b. Pasca pemberian pangan uji, kembali dilakukan pengukuran kadar glukosa darah pada menit ke, 15, 30, 45, 60, 90, dan 120.

c. Satu minggu kemudian, hal yang sama dilakukan dengan mengganti pangan acuan dengan pangan uji yang setara dengan $50 \mathrm{~g}$ karbohidrat kepada subjek.

\section{Pengolahan dan Analisis Data}

Hasil pengukuran respon glukosa individu pada pangan acuan dan pangan uji diolah dengan bantuan Microsoft Excel 2007. Dari data tersebut akan didapat kurva respon glukosa individu untuk kemudian dihitung luas area di bawah kurva. Sumbu X pada kurva merupakan nilai glukosa yang didapat dari pengambilan darah subyek dan sumbu $Y$ merupakan waktu dari pengambilan darah yang dilakukan. Luas area dibawah kurva tersebut analog dengan nilai indeks glikemik pangan yang diuji. Kemudian nilai indeks glikemik individu tersebut dirata-ratakan lalu dilakukan uji ragam terhadap masing-masing produk olahan jagung manis dengan bantuan SPSS 16.

\section{HASIL DAN PEMBAHASAN}

\section{Komposisi Zat Gizi Produk Olahan Jagung Manis}

Analisis komposisi zat gizi produk olahan jagung manis yang dilakukan meliputi analisis proksimat, total serat pangan, dan karbohidrat by difference/melalui perhitungan. Berikut disajikan hasil analisis komposisi zat gizi produk olahan jagung manis.

Tabel 1 menunjukkan bahwa air merupakan komponen terbesar dari ketiga jenis olah- 
Tabel 1. Hasil Analisis Komposisi Zat Gizi Produk Olahan Jagung Manis

\begin{tabular}{|c|c|c|c|c|c|c|c|c|}
\hline \multirow[b]{2}{*}{ Pengolahan } & \multirow[b]{2}{*}{ Basis } & \multicolumn{6}{|c|}{ Analisis Proksimat (\%) } & \multirow[b]{2}{*}{ KH tersedia (\%) } \\
\hline & & Air & Abu & Protein & Lemak & $\begin{array}{l}\text { Karbohidrat by } \\
\text { difference }\end{array}$ & $\begin{array}{c}\text { Serat } \\
\text { pangan }\end{array}$ & \\
\hline \multirow{2}{*}{ Rebus } & basis basah (bb) & 77.65 & 0.02 & 4.40 & 2.21 & 15.72 & 3.86 & 11.86 \\
\hline & basis kering (bk) & & 0.07 & 19.69 & 9.89 & 70.35 & 17.27 & \\
\hline \multirow{2}{*}{ Tumis } & basis basah (bb) & 63.80 & 0.04 & 5.49 & 14.63 & 16.04 & 3.39 & 12.65 \\
\hline & basis kering (bk) & & 0.12 & 15.16 & 40.41 & 44.31 & 9.36 & \\
\hline \multirow{2}{*}{ Bakar } & basis basah (bb) & 72.57 & 0.03 & 6.34 & 2.88 & 18.18 & 3.86 & 14.32 \\
\hline & basis kering (bk) & & 0.11 & 23.11 & 10.50 & 66.28 & 14.07 & \\
\hline
\end{tabular}

an jagung manis tersebut. Di antara ketiga jenis olahan jagung manis, pengolahan dengan cara direbus memiliki kandungan air terbesar yaitu sebanyak $77.65 \%$ hal tersebut disebabkan karena prinsip dalam proses pengolahan merebus adalah memasak menggunakan air (Widyati, 2004). Kandungan air terendah terdapat pada olahan jagung manis tumis hal tersebut disebabkan karena dalam proses pengolahannya, jagung manis tumis mengalami pemipilan terlebih dahulu. Proses ini menyebabkan air dari dalam jagung manis keluar. Selain itu dalam pemasakan jagung manis tumis juga tidak menggunakan air.

Kandungan protein dalam basis kering dari ketiga produk berkisar antara $15.16 \%$ 23.11\%. Penggunaan panas langsung pada bahan makanan menyebabkan permukaannya sering mengalami kegosongan padahal bagian dalamnya belum matang sempurna sehingga beberapa zat gizi seperti protein masih dalam keadaan utuh (Cameron 1985).

Kandungan lemak paling banyak terdapat pada olahan jagung manis tumis yaitu sebesar $40.41 \%$, yang diakibatkan karena proses pengolahan yang menggunakan margarin. Kandungan lemak paling sedikit terdapat pada jagung manis rebus.

Kadar abu yang dianalisis dapat meng gambarkan keberadaan mineral dalam pangan (Deman, 1997). Kadar abu jagung manis yang diteliti berkisar antara $0.07-0.12 \%$. Diduga keberadaan kandungan natrium dalam margarin yang digunakan dalam proses penumisan mempengaruhi kadar abu pada jagung manis tumis. Natrium merupakan salah satu mineral yang termasuk ke dalam golongan garam utama (Deman, 1997). Keempat komponen yang telah dianalisis sebelumnya akan digunakan untuk mengetahui kadar karbohidrat yang tersedia pada produk olahan jagung manis yang diteliti.

Kadar karbohidrat tersedia ditentukan dengan menggunakan pendekatan kadar karbohidrat by difference/melalui perhitungan yang telah dikurangi dengan kadar serat pangan total. Kadar karbohidrat yang tersedia digunakan sebagai dasar pada penentuan jumlah produk olahan jagung manis yang akan diberikan kepada subjek sebagai pangan uji pada penentuan indeks glikemik. Dari hasil perhitungan didapatkan karbohidrat yang tersedia untuk jagung manis rebus, tumis, dan bakar masing-masing sebesar $11.86 \%, 12.65 \%$, dan $14.32 \%$. Berdasarkan persentase tersebut maka diketahui jumlah jagung manis rebus, tumis, dan bakar yang diberikan kepada subjek penelitian secara berturut-turut adalah $422 \mathrm{~g}$, $395 \mathrm{~g}$, dan $350 \mathrm{~g}$.

Ketiga produk olahan jagung manis mengandung serat pangan total dalam basis kering antara 9.36 - $17.27 \%$. Hasil tersebut jauh lebih tinggi jika dibandingkan dengan hasil yang didapat oleh Huelsen (1954) pada jagung manis mentah, yaitu berkisar antara 1.1 2.2\%. Selain karena proses pemasakan, variasi kadar serat tersebut mungkin terjadi akibat perbedaan musim dan tempat tanam (Huelsen, 1954).

\section{Indeks Glikemik Produk Olahan Jagung Manis}

Tabel 2 memperlihatkan nilai indeks glikemik produk olahan jagung yang didapat dari nilai rata-rata enam orang subjek. Tabel tersebut menunjukkan bahwa dua dari tiga olahan jagung manis, yaitu rebus dan tumis masuk dalam kategori pangan rendah indeks glikemik berdasarkan pengkategorian menurut Miller 1996.

Tabel 2. Indeks Glikemik Produk Olahan Jagung Manis

\begin{tabular}{ccc}
\hline Pangan Uji & $\begin{array}{c}\text { Indeks } \\
\text { Glikemik (IG) }\end{array}$ & Kategori IG \\
\hline Jagung manis Rebus & 41.22 & rendah \\
Jagung manis Tumis & 31.088 & rendah \\
Jagung manis Bakar & 55.31 & sedang \\
\hline
\end{tabular}

Kategori pangan rendah dan sedang IG untuk ketiga produk olahan tersebut dapat disebabkan karena keberadaan serat dalam ja- 
gung manis sehingga proses pencernaan berjalan lebih lambat. Selain itu kandungan fruktosa yang terdapat di dalam jagung manis juga diduga menjadi faktor penyebab pangan yang diteliti memiliki indeks glikemik rendah dan sedang meskipun memiliki rasa yang manis.

Data mengenai nilai indeks glikemik jagung manis rebus dan beberapa varietas jagung manis dapat dilihat pada Tabel 3. Jagung manis rebus yang terdapat dalam Tabel 3 berasal dari varietas dan cara pengolahan yang berbeda dengan yang dilakukan dalam penelitian ini. Tapi dapat dilihat bahwa kedua termasuk dalam kategori pangan rendah IG.

Tabel 3. Nilai Indeks Glikemik Jagung Manis

\begin{tabular}{lc}
\hline \multicolumn{1}{c}{ Pangan } & Nilai IG \\
\hline Jagung Manis varietas Honey \& & $37 \pm 12$ \\
Pearl (New Zealand) & 48 \\
Jagung Manis tongkol, direbus 20 & $55 \pm 2$ \\
menit (Australia) & 60 \\
Jagung Manis (Cina) & $62 \pm 5$ \\
Jagung Manis (USA) & \\
Jagung Manis (Afrika Selatan) &
\end{tabular}

Sumber : Mendosa, 2008

Tabel 3 menunjukkan bahwa terdapat banyak variasi nilai indeks glikemik dari jagung manis. Hal ini dapat disebabkan karena perbedaan varietas dan cara pengolahan yang diterapkan pada penelitian terkait.

Jagung manis tumis memiliki nilai IG yang paling rendah diduga disebabkan karena pada proses pengolahannya menggunakan lemak dalam hal ini margarin. Meskipun memiliki nilai IG rendah, tidak berarti pangan ini direkomendasikan untuk penderita kegemukan maupun DM karena kandungan lemaknya yang tinggi. Menurut Rimbawan dan Siagian (2004), pangan berkadar lemak tinggi cenderung memperlambat proses pengosongan lambung sehingga menyebabkan laju pencernaan makanan di usus halus juga diperlambat. Oku et al. (2010) menyatakan bahwa pangan dengan IG rendah dapat menghasilkan banyak energi jika mengandung banyak lemak dan protein. Selain disebabkan karena penggunaan margarin dalam proses pengolahannya, nilai indeks glikemik yang rendah pada jagung manis tumis diduga juga disebabkan karena proses pemasakannnya yang relatif cepat.

Jagung manis rebus memiliki nilai indeks glikemik yang lebih tinggi dibandingkan dengan jagung manis tumis. Proses pengolahan yang menggunakan air dalam waktu yang cukup lama diduga menyebabkan peningkatkan daya cerna pati yang pada akhirnya akan meningkatkan nilai IG (Thornburn et al., 1986).

Tingginya nilai indeks glikemik jagung manis bakar dibandingkan dengan dua olahan lainnya disebabkan karena proses pengolahannya menggunakan panas yang cukup tinggi dan dalam waktu lama. Proses pengolahan seperti itu diperkirakan menyebabkan komponen karbohidrat pada jagung manis bakar lebih mudah dicerna dan diserap oleh tubuh sehingga menyebabkan respon glikemik yang lebih tinggi. Menurut Cameron (1985), pemasakan dengan metode panas kering, seperti pembakaran, menyebabkan karbohidrat pecah dan membentuk warna gelap (reaksi maillard). Hal ini mengindikasikan pecahnya pati sehingga membentuk dekstrin, bentuk yang lebih mudah dicerna.

Konsumsi pangan dengan nilai IG rendah diyakini memiliki keuntungan lebih dibandingkan dengan IG tinggi. Penerapan konsep IG selain berguna bagi orang yang perlu mengatur kadar glukosa darah tapi juga bermanfaat bagi orang sehat. Radulian et al. (2009) menyatakan bahwa konsumsi pangan rendah IG baik untuk menjaga sistem metabolisme tubuh. Hal serupa juga dinyatakan oleh Youqing $\mathrm{Hu}$ et al. (2006) dan Beulens et al. (2007).

Hasil penelitian Youqing $\mathrm{Hu}$ et al. pada tahun 2006 menunjukkan bahwa konsumsi pangan tinggi IG secara terus menerus dapat memicu meningkatnya stress oksidatif secara kronik. Diet rendah IG menunjukkan penurunan stress oksidatif. Stres oksidatif merupakan keadaan ketidakseimbangan antara produksi radikal bebas dengan pertahanan antioksidan in vivo. Penelitian Beulens et al yang dilakukan pada wanita paruh baya di Belanda, menunjukkan bahwa konsumsi pangan IG tinggi dapat meningkatkan risiko penyakit jantung.

Indeks glikemik bukan menjadi faktor tunggal yang harus dipertimbangkan dalam penentuan diet. Sebagai contoh adalah jagung manis tumis, yang dalam penelitian ini memiliki IG paling rendah. Jagung manis tumis menggunakan margarin yang mengandung asam lemak jenuh berupa palmitat dan stearat dalam proses pengolahan. Almatsier (2001) menyatakan bahwa peningkatan kolesterol darah dapat disebabkan oleh konsumsi lemak jenuh dalam makanan.

\section{Analisis Ragam}

Karena data respon glukosa darah yang didapat tidak menyebar normal, maka dilakukan uji ragam Kruskal Wallis dengan menggu- 
nakan median sebagai ukuran pemusatan dan penyebaran (Dahlan, 2009). Berikut ini disajikan nilai median dari IG yang didapat.

Tabel 4. Nilai Median IG

\begin{tabular}{cc}
\hline Pengolahan & IG (median) \\
\hline Rebus & 41.9338 \\
Tumis & 23.1322 \\
Bakar & 58.5379 \\
\hline
\end{tabular}

Terlihat bahwa nilai median IG dari jagung manis tumis dan bakar berbeda dengan nilai IG yang didapat dari rata-rata subjek. Hal ini disebabkan karena nilai IG dari rata-rata subjek merupakan nilai mean. Nilai mean merupakan total dari semua data kemudian dibagi dengan jumlah data. Sedangkan median merupakan nilai tengah dari data setelah diurutkan dari yang terkecil hingga terbesar. Namun bila dilihat dari kategori pangan berdasarkan IG maka nilai yang terdapat pada Tabel 4 termasuk dalam kategori yang sama dengan kategori dari nilai IG berdasarkan nilai rata-rata.

Hasil analisis ragam menggunakan uji Kruskal Wallis terhadap nilai indeks glikemik tiga pangan uji menunjukkan bahwa pengolahan tidak mempengaruhi nilai IG pada taraf nyata 5\%. Dengan demikian, pengolahan tidak terlalu mempengaruhi karakteristik jagung manis dalam hal nilai IG. Namun pemilihan cara pengolahan jagung manis yang sesuai untuk keadaan penyakit atau untuk menjaga kesehatan tetap perlu mempertimbangkan hal lain seperti kandungan zat gizi serta beban glikemik.

\section{KESIMPULAN}

Kadar air (bb) dalam jagung manis rebus, tumis, dan bakar masing-masing sebesar $77.65 \%$, 63.80\%, dan $72.57 \%$. Kadar protein (bk) pada jagung manis rebus, tumis, dan bakar berturut-turut sebesar 19.69\%, 15.16\%, dan $23.11 \%$. Kadar lemak (bk) dalam jagung manis rebus, tumis, dan bakar masing-masing sebesar $9.89 \%$, 40.41\%, dan $10.50 \%$. Kandungan karbohidrat by difference (bk) dalam jagung manis rebus, tumis, dan bakar masing-masing sebesar $70.35 \%, 44.31 \%$, dan $66.28 \%$. Serat pangan total (bk) yang dikandung jagung manis rebus, tumis, dan bakar masing-masing sebesar $17.27 \%$, 9.36\%, dan 14.07 .

Hasil pengukuran respon glikemik menunjukkan bahwa jagung manis rebus dan tumis memiliki nilai IG masing-masing sebesar 41.22 dan 31.08 dan termasuk pangan kategori
IG rendah. Jagung manis bakar memiliki indeks glikemik sebesar 55.31 dan termasuk ke dalam kategori pangan dengan IG sedang. Hasil analisis ragam menunjukan bahwa pengolahan tidak mempengaruhi nilai IG.

\section{DAFTAR PUSTAKA}

Almatsier S. 2001. Prinsip Dasar Ilmu Gizi. PT Gramedia Pustaka Utama, Jakarta.

Anonim. 2010. Teknologi untuk Meningkatkan Produksi Jagung. www.sinartani.com. [21 September2010]

Beulens JWJ et al. 2007. High dietary glycemic load and glycemic index increase risk of cardiovascular disease among middleaged woman. Journal of the American College of Cardiology, 50(1).

Cameron AG. 1985. The Science of Food and Cooking $3^{\text {rd }}$ Edition. Edward Arnold (Publishers) Ltd, London.

Dahlan MS. 2009. Statistik untuk Kedokteran dan Kesehatan. Salemba Medika, Jakarta.

Deman JM. 1997. Kimia Makanan (Kosasih Padmawinata, penerjemah). Penerbit ITB, Bandung.

Fardiaz D et al. 1984. Penuntun Praktikum Analisa Pangan. Fakultas Teknologi Pangan, IPB, Bogor.

Huelsen WA. 1954. Sweet Corn. Interscience Publisher Inc, New York.

Mendosa D. 2008. Revised International Table of Glycemic Index (GI) and Glycemic Load (GL) Values-2008. www.mendosa. com. [21 September 2010]

Miller JB, powell KF, \& Colagiuri S. 1997. The GI factor; The GI Solution. Hodder and Stoughton, Hodder Headline, Australia.

Oku, Tsuneyuki, Mariko N, Sadako N. 2010. Consideration of the validity of glycemic index using blood glucose and insulin levels and breath hydrogen. International Journal of Diabetes Mellitus, 2, 88-94.

Palungkun R \& Budiarti A. 1992. Sweet Corn Baby Corn. P Jakarta, Penebar Swadaya. 
Radulian, Gabriel, Emilia R, Andreea D, \& Mihaela P. 2009. Metabolic effect of low glycaemic index diets. Nutritional Journal, 8,5 .

Rimbawan \& Siagian A. 2004. Indeks Glikemik Pangan. Penerbit Swadaya, Jakarta.

Sherwood L. 2001. Fisiologi Manusia dari Sel ke Sistem. (Brahm U. Pendit, penerjemah). Penerbit Buku Kedokteran EGC, Jakarta.

Thornburn AW, Brand JC, \& Truswell AS. 1986. The Glycemic Index of Food. The
Medical Journal of Australia, 144, 580 582.

Widowati S dkk. 2006. Hypoglycemic Activity of Some Indonesian Rice Varieties and Their Physicochemical Properties. Journal of Agricultural Science 7(2), 57 - 66

Widyati R. 2001. Pengetahuan Dasar Pengolahan Makanan Indonesia. PT Grasindo, Jakarta.

Youqing, Hu, Gladysa Block, Edward PN, Jason DM, Marion D, \& Mark H. 2006. Relations of glycemic load with plasma. 